\title{
Does G6PD deficiency protect against cancer? A critical review
}

\author{
PIERLUIGI COCCO \\ From the Istituto di Medicina del Lavoro, Università di Cagliari, Italy
}

SUMMARY Previous observations on the lower mortality for cancer experienced in populations with a higher frequency of G6PD deficiency support biochemical studies on the role of G6PD during cell proliferation. The general agreement among experimental studies prevented a deeper analysis of the sources of what has been called "epidemiological evidence of the protective role of G6PD deficiency against cancer". This review analyses the methods and findings in those papers, stressing their limitations and emphasising that no final conclusions can be drawn from them. Preliminary results of ongoing epidemiological studies of G6PD deficiency and cancer are presented, although they do not prove or disprove the hypothesis that G6PD deficiency protects against cancer.

Glucose-6-phosphate dehydrogenase (G6PD) deficiency is an hereditary condition transmitted by a sex-linked gene with intermediate dominance in females. It is fairly frequent among Mediterranean populations, and its consequences were known more than 2000 years ago: Herodotus recorded that Egyptian priests were not allowed to eat broad beans (Vicia faba) because of the occurrence of symptoms which we now attribute to haemolytic crises. Pythagoras, according to historians, chose to be captured by enemies rather than try to escape through a broad bean field.

Even though haemolytic anaemia is the only known disease occurring in G6PD deficient subjects, G6PD deficiency has been demonstrated in other tissues as well. ${ }^{1-7}$ The particular position of G6PD in the metabolic pathway leading to nucleic acid synthesis supported the hypothesis that its deficiency interferes with normal cell function and replication ${ }^{89}$ and leads to a protective effect against the development of cancer.

A first impulse to study the relation between G6PD deficiency and the incidence of cancer came from the observation of the geographical variability of both factors, sometimes inversely related. ${ }^{9}$ In the years 1968-72, a few papers were published all supporting the hypothesis of a lower cancer incidence in G6PD deficient subjects. We examine the methods and findings of these papers, which were thought to supply epidemiological evidence of a lower cancer incidence in G6PD deficient subjects.

\section{Review of the literature}

About 20 years ago, Beaconsfield et al., utilising official records from the World Health Organization and the Ministry of Health of Israel, reported standardised mortality rates for four tumours (stomach, kidney, colon, pancreas) in Occidental and Oriental Jews; ${ }^{9}$ in all cases, and more clearly in males, the incidence of cancer was higher in Occidental than in Oriental Jews (table 1). The estimate of the frequency of G6PD deficiency in the different ethnic groups living in Israel was indirectly obtained from a previous study on the frequency of glutathione stability in those populations. ${ }^{10}$ The stability of glutathione (GSH) inside the red cells is strictly

Table 1 Cancer rates for selected sites, standardised for sex and age, per $10^{-5}$ Israeli Jewish immigrants aged 65 and over (from Beaconsfield et al.)

\begin{tabular}{lrrrrr}
\hline \multirow{2}{*}{ Tumour site } & \multicolumn{2}{l}{ Occidental Jews } & & \multicolumn{2}{l}{ Oriental Jews } \\
\cline { 2 - 3 } \cline { 5 - 6 } \cline { 5 - 6 } & Men & Women & & Men & Women \\
\hline Stomach & 258.0 & 157.0 & & 120.2 & 90.9 \\
Colon & 70.2 & 54.4 & & 22.0 & 31.6 \\
Pancreas & 48.3 & 27.6 & & 24.0 & 31.6 \\
Kidney & 35.6 & 20.7 & & 10.0 & 7.4 \\
\hline
\end{tabular}


dependent on the availability of a sufficient G6PD activity, of which it was considered as an approximate estimate. Thus males with unstable GSH were thought of as always being G6PD deficient; on the other hand, the same condition in females co-existed with various degrees of enzyme activity. Table 2 shows only data for males; extreme variability in the frequency of unstable GSH (= G6PD deficiency) is evident among the ethnic groups within the 'Oriental Jews' category. Unfortunately, it was impossible to single out the mortality rates for cancer in these groups, but the difference observed in the official records seemed to be sufficient to suggest that G6PD deficiency may have been involved in protecting Oriental Jews against cancer, bearing in mind that:

(a) the discrepancy in the rate of malignancies between the two Israeli population groups was far greater than would seem to be justified on the sole basis of G6PD deficiency percentages established for these populations;

(b) the rough subdivision of compared groups, and particularly the heterogeneity of the Oriental Jew category, did not allow Beaconsfield to exclude other criteria, including environmental and hereditary factors;

(c) the limit inherent in retrospective studies becomes much more evident as far as this topic is concerned because, he wrote, "in a person with G6PD deficiency, the level of the enzyme becomes normal or even elevated, consequent to severe injury or during neoplastic changes." Thus he suggested the possibility of a misclassification of G6PD activity due to the neoplastic disease.

Finally, Beaconsfield indicated the necessity of carrying out longitudinal investigations to obtain sufficient evidence about the pattern and significance of the relation between G6PD deficiency and the malignant process.

Three years later, following Beaconsfield's hypothesis, Sulis and Spano published a paper reporting their case-record of palate tumours; G6PD deficient subjects accounted for $7 \%$ of the total number of cases $(11 / 140)$, whereas they estimated at about $13-15 \%$ the frequency of the same condition in the whole Sardinian male population. ${ }^{11} 12$ These authors also reported that most cases were smokers "a fogu a intru" (Sardinian term describing the particular method of smoking cigars with the lighted side inside the mouth); four out of eight G6PD deficient cases with more advanced lesions and treated only with radiotherapy still survived six to seven years after diagnosis and were apparently cured, thus suggesting that there is less malignancy in the evolution of cancer in G6PD deficient subjects.

Before any treatment was given, the authors ascertained the presence of G6PD activity in the neoplastic tissue of three of the four cases previously mentioned. It was at a lower level than in neoplastic tissue of individuals with normal G6PD activity in red cells, and they used this finding to support their hypothesis of a lower malignancy in neoplastic lesions of G6PD deficient subjects. The following facts should be noted:

1 The authors did not describe the study as an epidemiological one.

2 For comparison, the authors chose data on the frequency of G6PD deficiency in the Sardinian population published by Siniscalco et al in 1961.12 They studied a random sample of 2459 school boys in 19 Sardinian villages, 339 of whom $(13.8 \%)$ were found to be G6PD deficient. But, what is most important, the range of variation among the villages examined was $3-35 \%$, very well related to past malarial frequency and, inversely, to altitude. The same characteristics of geographical distribution were then confirmed by other studies. ${ }^{13}$

3 The practice of smoking with the lighted end of the cigar inside the mouth was particularly prevalent among the shepherds of Central Sardinia; cancer of the oral cavity and pharynx (including palate cancer) is more frequent there than in the rest of the region. ${ }^{14}$ This area is geographically mountainous and in the past was practically free of malaria. Thus, as demonstrated by all population studies of G6PD deficiency in Sardinia, the local frequency of the enzyme deficiency is lower than in the rest of the

Table 2 Frequency of GSH instability (associated with G6PD deficiency in random samples of males from different population groups (from Szeinberg et al.))

\begin{tabular}{|c|c|c|c|c|}
\hline Population group & No of males examined & $\begin{array}{l}\text { Unstable } \\
\text { No }\end{array}$ & $\underset{\%}{G S H}$ & $\begin{array}{l}\text { Mortality rates for } \\
\text { cancer (all types) }+\end{array}$ \\
\hline $\begin{array}{l}\text { Ashkenazi* } \\
\text { Not Ashkenazi* } \\
\text { Subgroups: Iraq } \\
\begin{array}{ll}\text { Yemen } \\
\text { North Africa } \\
\text { Others }\end{array}\end{array}$ & $\begin{array}{r}203 \\
174 \\
72 \\
42 \\
24 \\
36\end{array}$ & $\begin{array}{r}\overline{18} \\
15 \\
2 \\
1 \\
-\end{array}$ & $\begin{array}{c}- \\
10 \cdot 4 \\
20 \cdot 8 \\
4 \cdot 8 \\
4 \cdot 1 \\
-\end{array}$ & $\begin{array}{l}195.0 \times 10^{-5} \\
128.0 \times 10^{-5} \\
- \\
- \\
-\end{array}$ \\
\hline
\end{tabular}

- Ashkenazi are Western Jews; Not Ashkenazi are Eastern Jews (including also Spanish, Portuguese, Moroccan, Turkish, and Iraqui groups)

+ Mortality rates for cancer are adjusted for age (over 15 years) not sex. 
region. It is possible then that a bias affected the study of Sulis and Spano: the risk of palate cancer may be related not to normal G6PD activity, but rather to the particular method of smoking cigars, which happened to be very common in that same area where G6PD deficiency is rare.

In a further paper, Sulis reported a case-record of 320 males affected by cancer (all types), resident in the area near Cagliari, 13\% of whom were G6PD deficient, ${ }^{15}$ while $25-35 \%$ of the total male population in the same area were G6PD deficient. Some further considerations are as follows:

1 A control group is again lacking.

2 The reported frequency of G6PD deficiency in the cases of cancer is very close to the mean frequency of G6PD deficiency in the Sardinian male population. ${ }^{121316}$

3 Up to the 1970s the "area of Cagliari" received immigrants from the whole island; thus it is more important to know, before comparing them, where the people affected by cancer were born rather than where they were residing.

4 In the same paper, a lower cancer prevalence is reported for Sardinia than for both northern Italy and the rest of Europe. ${ }^{15}$ We must recall that the standardised mortality rate for cancer (all types) in the Sardinian male population ranged from 12.8 to $14 \times 10^{-4}$ in the period $1970-79$, still lower than for North and Central Italy but almost always higher than for the remaining regions of Southern Italy where G6PD deficiency is practically unknown. ${ }^{16} 17$

As further support for this suggestive hypothesis, another paper appeared in which Naik and Anderson reported their study on erythrocyte G6PD deficiency in 241 Negro patients (66 males and 175 males) affected by cancer and compared them with 266 Negro male blood donors and 142 females attending planned parenthood and maternity clinics. ${ }^{18}$

The different prevalence among the female sex in the two groups compared does not allow any inference without a stratification by sex. Actually it is known that because of the particular genetic transmission of the character, G6PD deficiency is much more frequent everywhere in males than in females; so, having a higher percentage of females among cases and of males among controls means that cases will be less frequently G6PD deficient, as Naik and Anderson reported in 1970. ${ }^{19}$ Dividing the same cases and controls according to sex, no significant difference was found between males; on analysing the data statistically, again with the chi-square test according to the MantelHaenszel procedure, ${ }^{20}$ even the reported significance of the difference in the female sex disappeared (table 3).

Furthermore, another study by Long et al ${ }^{21}$ did not reveal a significant negative relation between G6PD
Table 3 Frequency of G6PD deficiency in Negro cancer patients and controls

\begin{tabular}{llcc}
\hline Group & & Total No. & G6PD deficient \\
\hline Cases & Male & 66 & $3(4.5 \%)^{*}$ \\
& Female & 175 & $1(0.6 \%) \dagger$ \\
Controls & Male & 266 & $25(9.4 \%)^{*}$ \\
& Female & 130 & $5(3.8 \%)$ \\
\hline
\end{tabular}

${ }^{*} \chi^{2}=1.8 ;$ OR $=0.46 ;$ OR, $\overline{\mathrm{OR}}=0.15,1.41$

$+\chi^{2}=2.6 ; O R=0.14 ; \overline{O R}, \overline{O R}=0.01,1.54$

(from Naik and Anderson)

OR, $\overline{O R}=95 \%$ confidence limits.

deficiency and cancer; we analysed their data again according to the case-control method (table 4). G6PD deficient subjects showed a significant positive risk for varicose veins, congenital anomalies, and cataract, and a negative risk for coronary artery disease. No relation existed between malignancies and G6PD deficiency; the statistical power was too small to demonstrate the negative risk found for carcinoma in G6PD deficient subjects. Unfortunately, no list of tissues or organs affected by carcinoma was given, nor were the types of cancer included in the malignancies indicated.

\section{Conclusions}

Even though there is no clearcut evidence of a negative association between G6PD deficiency and the incidence of cancer, the authors who studied these topics gave a great impulse to further investigations of the epidemiology of G6PD and associated diseases.

In recent years, different authors have discovered a relation between G6PD enzymatic activity, cell proliferation, and cancer. Schwartz et al have repeatedly shown that G6PD inhibition by dehydroepiandrosterone (DHEA) protects against the growth of chemically induced tumours and is also able to block cell division and proliferation. ${ }^{24-26}$

On the other hand, it was shown that the inhibition of tumour induction may be due to the failure of

Table 4 Odds ratio for some diseases in G6PD deficient Negro male patients (Further analysis of data from Long et al.)

\begin{tabular}{llrll}
\hline Disease & $O R$ & $\chi^{2}$ & $\underline{O R}$ & $\overline{O R}$ \\
\hline Coronary artery disease & 0.48 & 4.56 & 0.24 & 0.94 \\
Hypertension & 1.49 & 2.74 & 0.93 & 2.39 \\
Varicose veins & 3.71 & 14.02 & 1.88 & 7.34 \\
Congenital anomalies & 3.03 & 6.77 & 1.32 & 6.96 \\
Carcinoma & 0.37 & 2.79 & 0.12 & 1.18 \\
Malignancy (all types) & 0.95 & 0.02 & 0.46 & 1.94 \\
Cataract & 2.01 & 5.14 & 1.10 & 3.66 \\
Inguinal hernia & 1.53 & 2.40 & 0.90 & 2.61 \\
\hline
\end{tabular}

OR. $\overline{\text { OR }}=95 \%$ confidence limits 
Table 5 Comparison of height and weight of G6PD deficient and normal subjects (workers admitted to the same hospital for occupational diseases)

\begin{tabular}{|c|c|c|c|}
\hline$G 6 P D$ & No. & $\begin{array}{l}\text { Height } \\
(\mathrm{cm})\end{array}$ & $\begin{array}{l}\text { Weight } \\
\text { (kg) }\end{array}$ \\
\hline $\begin{array}{l}\text { Deficient } \\
\text { Normal }\end{array}$ & $\begin{array}{l}30 \\
62\end{array}$ & $\begin{array}{l}163.0 \pm 6.63 \\
164.87 \pm 5.73^{*}\end{array}$ & $\begin{array}{l}69.1 \pm 9.45 \\
70.9 \pm 13.85 t\end{array}$ \\
\hline
\end{tabular}

$* t=-2.31 \quad p<0.05$

$t \mathrm{t}=-3.35 \quad \mathrm{p}<0.01$

G6PD deficient cells to metabolise chemicals to the ultimate form that is able to induce cancer. ${ }^{27}$

A positive correlation has repeatedly been reported between DNA synthesis and G6PD activity, suggesting that the hexose-monophosphate shunt may be limiting for cell proliferation by not providing enough nicotinamide-adenine-dinucleotide-phosphate (NADPH) for the synthesis of cholesterol and its intermediate metabolites, which are known to be necessary for initiating DNA sythesis. ${ }^{28-31}$

No epidemiological evidence, as we have previously stated, can be obtained from the existing literature, starting from the early 1960s when epidemiological methods were not yet so refined. Our first approach was to check whether in normal subjects it would be possible to find a relation between physiological growth and G6PD deficiency; both height and weight were found to be lower in G6PD deficient subjects than in normal individuals, even though the difference was not as great as we expected, considering that the G6PD deficiency greatly restricted normal cell proliferation and growth (table 5).

The next step was a geographical correlation of the frequency of G6PD deficiency and standardised mortality rates for cancer (all types), using data for the

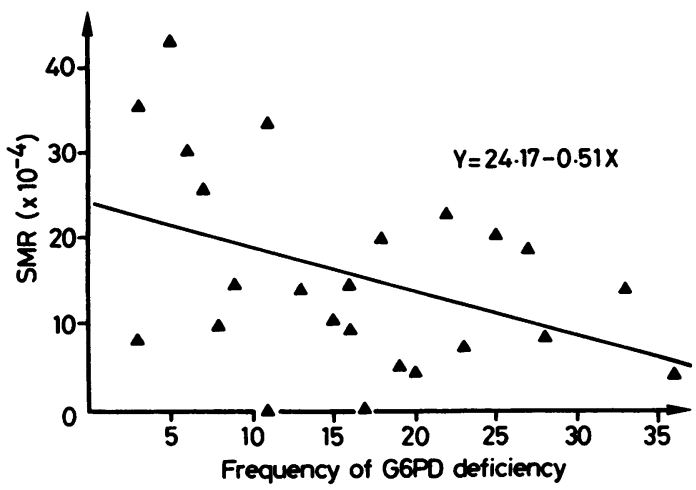

Linear regression between frequency of G6PD deficiency and standardised mortality rate for cancer (all types) in the male populations of 24 Sardinian towns: $r=-0.418, p<0.05$. male population of 24 Sardinian towns, whose G6PD deficiency frequencies were almost continuously distributed (figure). The simple correlation coefficient calculated was statistically significant, but both the large variability of SMRs and the non random selection of samples examined did not allow any conclusion to be drawn. ${ }^{13}$

Beaconsfield's indication of the need for a $\overrightarrow{\vec{F}}$ longitudinal study for the purpose of ascertaining a possible protective role of G6PD deficiency against cancer still remains to be satisfied.

Special thanks are given to: Professor P Pani for helpful discussions and suggestions; Mrs Brunetti and Mrs Savona (CED Regional Administration) for kind and indispensable collaboration; and Miss A Pisano for typing the manuscript.

Address for reprints: Dr Pierluigi Cocco, Istituto di Medicina del Lavoro, Università di Cagliari, via S Giorgio 12, 09100 Cagliari, Italy.

\section{References}

${ }^{1}$ Ramot B, Szeinberg A, Adam A, Sheba C, Gafni D. A study of subjects with erythrocyte glucose-6-phosphate dehydrogenase deficiency: investigation of platelet enzymes. J Clin Invest 1959; 30: 1659-61.

2 Ramot B, Szeinberg A, Adam A, Sheba C, Gafni D. A study of subjects with erythrocyte glucose-6-phosphate dehydrogenase deficiency: investigation of leucocytic enzymes. J Clin Invest 1959; 30: 2234-7

${ }^{3}$ Ramot B, Sheba C, Adam A, Ashkenazi I. Erythrocyte G6PD deficient subjects: enzyme levels in saliva. Nature 1960; 185: 931.

${ }^{4}$ Marks PA, Gross RT. Erythrocyte G6PD deficiency. Evidence of differences between Negroes and Caucasians with respect to this genetically determined trait. J Clin Invest 1959; 38: 2253-62.

${ }^{5}$ Panizon F. Studio sull'attività enzimatica della mucosa digiunale in soggetti con G6PD-penia eritrocitaria. Studi Sassaresi 1961; 39: 710-8.

${ }^{6}$ Pannacciulli I, Tizianello A, Salvidio E. L'attività della G6PD e 6PGD dei leucociti, delle piastrine, delle cellule midollari, spleniche, epatiche e di tessuto gastrico in soggetti con eritroenzimopenia familiare. Boll Soc It Biol Sper 1966; 42: 1552-5.

${ }^{7}$ Brunetti P, Rossetti R, Broccia G. Nuove acquisizioni in tema di bioenzimologia del favismo ittero- $N$ emoglobinurico. III: L'Attività glucosio-6-fosfatodeidrogenasica del parenchima epatico. Rass Fisiopat Clin Ter 1960; 32: 338-44.

8 Beaconsfield P, Reading HW. Pathways of glucose metabolism and nucleic acid synthesis. Nature 1964; 202: 464-6.

${ }^{9}$ Beaconsfield P, Rainsbury R, Kalton G. Glucose-6phosphate dehydrogenase deficiency and the incidence of cancer. Oncologia 1965; 19: 11-9. 
${ }^{10}$ Szeinberg A, Sheba C, Adam A. Selective occurrence of glutathione insufficiency in the red blood corpuscles of various Jewish Tribes. Blood 1958; 13: 1043-53.

11 Sulis E, Spano G. Osservazioni preliminari sull'incidenza neoplastica e sul comportamento enzimatico e proliferativo del tessuto tumorale negli individui carenti di glucosio-6-fosfato deidrogenasi (G6PD). Boll Soc It Biol Sper 1968; 44: 1246-9.

12 Siniscalco M, Bernini L, Latte B, Motulsky AG. Favism and thalassaemia in Sardinia and their relationship to malaria. Nature 1961; 190: 1179-80.

${ }^{13}$ Cocco PL, Manca P, Dessi S. Preliminary results of a geographic correlation study on G6PD deficiency and cancer. Toxicol Pathol in press.

${ }^{14}$ Istituto Centrale di Statistica: Annuario di statistiche sanitarie. Vol. 17 Roma: ISTAT Ed, 1974; 213.

15 Sulis E. G6PD deficiency and cancer. Lancet 1972; i: 1185.

16 Salvidio E, Pannacciulli I, Tizianello A, Gaetani G, Paravidino G. Glucose-6-phosphate dehydrogenase deficiency in Italy. Acta Haemat 1969; 41: 331-40.

${ }^{17}$ Capocaccia E, Farchi G, Mariotti S, Verdecchia A, Angeli A, Morganti P, Panichelli Fucci M L. La mortalità in Italia nel periodo 1970-1979. Istisan Ed., Roma, 1984: 44-5.

${ }^{18}$ Naik SN, Anderson DE. The association between glucose6-phosphate dehydrogenase deficiency and cancer in American Negroes. Oncology 1971; 25: 356-64.

${ }^{19}$ Naik SN, Anderson DE. G6PD deficiency and cancer. Lancet 1970; i: 1060-1.

${ }^{20}$ Mantel N, Haenszel W. Statistical aspects of the analysis of data from retrospective studies. J Nat Cancer Inst 1959; 32: $719-48$.

${ }^{21}$ Long WK, Wilson SW, Frenkel EP. Associations between red cells glucose-6-phosphate dehydrogenase variants and vascular diseases. Am J Hum Gen 1967; 19: 35-53.

${ }^{22}$ Schwartz AG, Perantoni A. Protective effect of dehydroepian drosterone against aflatoxin $B_{1}$ - and 7,12Dimethylbenz(a)anthracene-induced citotoxicity and transformation in cultured cells. Cancer Res 1975; 35: 2452-7.
${ }^{23}$ Schwartz AG, Tannen RH. Inhibition of 7,12dimethylbenz(a)anthracene- and urethane-induced lung tumour formation in $\mathbf{A} / \mathbf{J}$ mice by long-term treatment with dehydroepiandrosterone. Carcinogenesis 1981; 2: 1335-7.

${ }^{24}$ Schwartz AG, Pashko LL, Henderson EE, Tannen RH, Cleasy MP, Abou-Gharbia M, Swern D. Dehydroepiandrosterone: an anti-obesity and anticarcinogenic agent. Comm Res Breast Dis 1983; 3: 113-30.

${ }^{25}$ Schwartz AG, Nyce JW, Tannen RH. Inhibition of tumorigenesis and autoimmune development in mice by dehydroepiandrosterone. In: Altered endocrine status during aging, Liss AR, Ed. New York; 177-84.

${ }^{26}$ Pashko LL, Hard GC, Rovito RJ, Williams JR, Sobel EL, Schwartz AG. Inhibition of 7,12-dimethylbenz(a) anthracene-induced skin papillomas and carcinomas by dehydroepiandrosterone and 3-beta-methylandrost-5en-17-one in mice. Cancer Res 1985; 45: 164-6.

${ }^{27}$ Feo F, Pirisi L, Pascale R, Daino L, Frassetto S, Garcea R, Gaspa L. Modulatory effect of glucose-6-phosphate dehydrogenase deficiency on benzo(a)pyrene toxicity and transforming activity for in vitro-cultured human skin fibroblasts. Cancer Res 1984; 44: 3419-25.

${ }^{28}$ Dessi S, Batetta B, Laconi E, Ennas C, Pani P. Hepatic cholesterol in lead nitrate induced liver proliferation. Chem Biol Interact 1984; 48: 271-9.

${ }^{29}$ Pani P, Dessi S, Rao KN, Batetta B, Laconi E. Changes in serum and hepatic cholesterol in lead induced liver hyperplasia. Toxicol Pathol 1984; 12: 162-7.

${ }^{30}$ Ledda-Columbano GM, Columbano A, Dessi S, Coni P, Chiodino C, Pani P. Enhancement of cholesterol synthesis and pentose phosphate pathway activity in proliferating hepatocyte nodules. Carcinogenesis 1985; 6 : 1371-3.

31 Dessi S, Chiodino C, Batetta B, Laconi E, Ennas C, Pani P. Hexose monophosphate shunt and cholesterol synthesis in the diabetic and fasting states. Exp Mol Path 1985; 43: 177-86. 